\title{
Relationship between attitude, subjective norm, and perceived behavioural control of learning practices among boarding school students
}

\author{
Norlia Norlia ${ }^{1}$, Mastura Mastura ${ }^{2}$ \\ ${ }^{1}$ SM Sains Batu Pahat, Malaysia \\ ${ }^{2}$ Universiti Teknologi Malaysia, Malaysia
}

\section{Article Info \\ Article history: \\ Received Jan $11^{\text {th }}, 2020$ \\ Revised Feb 25 ${ }^{\text {th }}, 2020$ \\ Accepted Mar $15^{\text {th }}, 2020$}

\section{Keyword:}

Attitude

Subjective Norm

Perceived Behavioral Control

Learning Practice

\begin{abstract}
This study was conducted based on the Theory of Planned Behaviour by Ajzen 1991 aimed at identifying the relationship between attitude, subjective norm and perceived behavioural control to learning practices among students of Boarding Schools (SBP). This study uses a correlation research design involving a sample of 200 low-achieving Form Four students from four SBPs in Johor selected through purposeful random sampling. A Learning Practice Questionnaire by Norlia and Faizah 2016 with values of item (0.98) and individual (0.88) reliability based on RASCH analysis was used to collect the data. The result of the inferential statistical analysis using Pearson correlation shows that there is a significant positive relationship between attitude and subjective norms learning practices $(\mathrm{r}=0.44, p<.05)$, attitude with perceived behavioural control learning practices $(\mathrm{r}=0.41, p<.05)$ and subjective norms with perceived behavioural control learning practice $(\mathrm{r}=0.31, p<.05)$. Therefore, this study proves that attitude, subjective norms and perceived behavioural control of learning practices are interrelated. Hence, SBP students need to have these three elements to increase the potential of learning practices towards achieving excellence.
\end{abstract}

(C) 2020 The Authors. Published by Redwhitepress

This is an open access article under the CC BY-NC-SA license

(https://creativecommons.org/licenses/by-nc-sa/4.0/

\section{Corresponding Author:}

Norlia Norlia

SM Sains Batu Pahat

Email: lilyryhanee@yahoo.com

\section{Introduction}

Good learning practice is an important factor to be emphasized on each student (Heritage, 2020). Manners in learning is a fundamental thing that must be learned and practiced by every student before learning other sciences (Asy'ari, 2011). This is because, good leaning practices can help students to learn and understand the lessons more easily (Beninghof, 2020; Noordin, 2007). Abdullah ibn al Mubarak (Kadir, 2014) said that he studied manners for thirty years and studied other sciences for twenty years. Students should be aware of the nature of this importance and endeavour to exercise the manners of learning practices before, during and after studying. For example, Imam al-Ghazali stated that there are seven learning manners that a student should practice: abstaining from disgraceful conduct, reducing relations with others, not arrogant to knowledge and leave the business of knowledge to teachers, should not listen to disputes between others, do not reject the praiseworthy knowledge, devote all the ability to study knowledge and strive to achieve the pleasure of Allah swt (Yasin, 2012). Imam Syafie reminded students to always listen with full concentration of the teacher's delivery, not disturb the course of the knowledge gathering, have the intention to convey and 
practice the learned knowledge (Ghazali, 2015), be moderate when eating, abstain from anything vice, focus entirely on the lesson by limiting other busyness and respect the teacher (Aziz, 2007; Costa, 2020). While Sheikh Az Zarnuji stated that students need to set the right intentions to learn, to choose a good friend, to glorify teachers, to work hard and to work hard, to study according to their level and ability, to trust Allah SWT, to determine the time of study, to seek the benefits of knowledge which is learned and be pious in learning (Thohir, Alfina, \& Dardiri, 2017).

Based on the recommendations and reminders of the above Islamic scholars, a good practice of learning can be understood as a positive and polite behaviour that is habitual to students during the process of acquiring knowledge (Norlia, 2017; Oates, 2020). However, there are still many students who are less concerned with the learning practices when studying especially among the low achievers in SBP. Studies by Ishak (1991), Thilaga (2004) and Genevy (2006) in SBP have found that SBP students with low achievements apply learning practices that are contrary to the learning manners according to Islamic perspective . Low-achievement SBP students are found to be frequently procrastinating, seldom read books, less preoccupied with study notes, only review lessons near to exams, seldom do exercises and only study when encouraged by teachers and parents. Low-achievement SBP students bully fellow schoolmates (Samad, 2007; Zadzora, 2019), less friendly with teachers, often blame teachers when they are not interested in certain subjects and reluctant to ask teachers questions when studying (Kitchen, 2020; Uning \& Mohamed, 2006).

There are various factors that cause low-achieving SBP students to seldom apply good learning practices. The most important factor is the intention to apply the good learning practices without strong intention, a behaviour is difficult to happen (Ajzen, 1991; Sadaf \& Gezer, 2020). However, behavioural intention is influenced by a combination of attitude, subjective norm, and perceived behavioural control . Attitude is an individual's overall evaluation of the behaviour, whether it is positive or negative (Ajzen, 1991). Subjective norm is a social factor term that (Ajzen, 2005) refers to one's perception towards social pressure received from people who are considered important in one's life, whether to engage in a behaviour (Ajzen \& Fishbein, 2000), while perceived behavioural control includes real barriers and assessments of limitations or abilities of target behaviour (Acevedo, 2012; Steege, Pratt, Wickerd, Guare, \& Watson, 2019).

Thus, this study was conducted to identify the relationship between attitude, subjective norms and perceived behavioural control to learning practices among SBP students in the low achievement category in Johor. By identifying the extent of the relationship, the researcher can also determine the potential behavioural intention in the students to apply the learning practices.

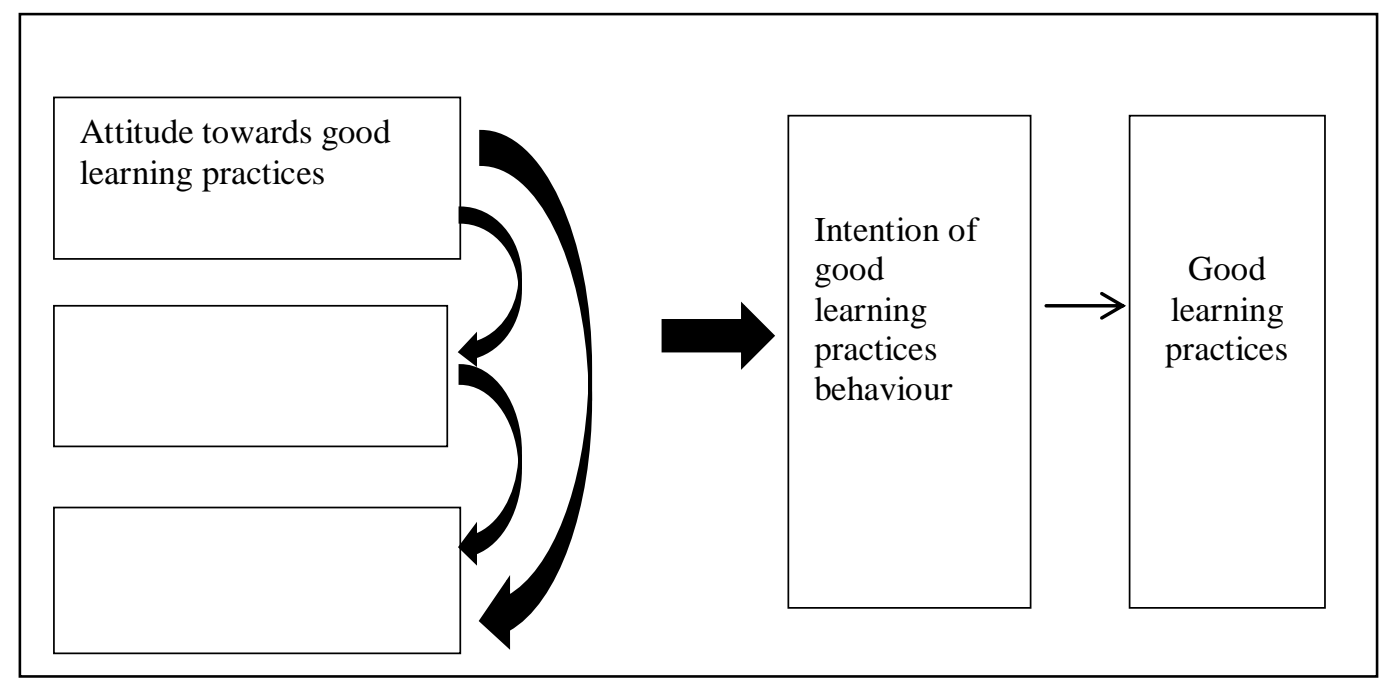

Figure 1: Conceptual Framework

Based on Figure 1 above, it can be seen that attitude, subjective norm and perceived behavioural control can instil intentions to apply good learning practices behaviour and subsequently the practices of manners in learning. This conceptual framework is based on the Theory of Planned Behaviour (Ajzen, 1991) while learning manners is based on the Islamic perspective of Imam al-Ghazali (Yasin, 2012).

The development and change of a person's behaviour occur due to the consequence of attitude towards behaviour, perceived behavioural control and subjective norms that shape the behavioural intention before the actual behaviour materialised (Ajzen, 2011). Attitude towards behaviour refers to an individual's overall 
assessment of behaviour whether positive or negative, based on the belief in behaviour and the effect of doing the behaviour whether good or bad (Francis, et al., 2004). Subjective norm, on the other hand, is the social factor that refers to one's perceptions of social pressure received from people who are considered important in their lives, on whether to engage or not to engage in a certain behaviour (Ajzen, 2011; Ajzen \& Fishbein, 2000). Perceived behavioural control is the perception of how difficult or easy for a person to do a certain behaviour (Kraft, Rise, Sutton, \& Røysamb, 2005; Sun, Law, \& Schuckert, 2020).

The good manners of learning practices are based on the Islamic perspective of Imam al-Ghazali, which are practicing good diet, maintaining the purity of the heart, maintaining relationship boundary, studying earnestly, respecting teachers, taking down notes and practicing knowledge (Yasin, 2012). Practicing good diet includes halal status, cleanliness and balanced nutritional factors (Salim, 2014)because nutrition can affect the process of growth, personal development, behaviour and mind formation (Noordin, 2007). Maintaining the purity of the heart is necessary because as long as the heart is not clean from acts of immorality, the heart cannot receive the beneficial knowledge because as said by Ibnu Mas'ud r.a " Knowledge is not about how much you can recite, but knowledge is the light that is bestowed in your heart" (Al-Ghazali, 2012).

Furthermore, Imam al-Ghazali also suggested that students limit their relationship with others (A1Ghazali, 2012; Yasin, 2012) as many friends can cause students to be busy, waste time and also age (Aziz, 2007). Students also need to study hard because if someone is far from knowledge, then his heart will be ill and die (Al-Khaleel, 2011; Al-Qasimi, 2010). Respecting the teacher, in his presence or not, helps the students to get guidance and direction from Allah SWT especially in pursuing knowledge (Ismail, 2014). Lastly, students need to practice the learned knowledge to increase consciousness and to be easily guided by Allah SWT (Embong, Safar, \& Basiron, 2020). Thus, based on the Theory of Planned Behaviour (Ajzen, 1991, 2011), the researchers emphasized on attitude, subjective norms and perceived behavioural control towards the learning practices in order to see the potential intention and behaviour of practicing good learning manners among low achievement SBP students.

\section{Method}

A researcher should set the design of a research to be carried out so that the implementation can produce convincing evidence to answer the research questions based on the sources obtained (Lawrence, 2020). As this study aims to identify the extent of relationship between attitude, subjective norm and perceived behavioural control, it is carried out using a correlational study design. A quantitative research with a correlation design is a study that involves data collection to identify whether there is a relationship between two or more variables (Gay, 2009; Roni, Merga, \& Morris, 2020).

The population for this study is low achievement SBP students who achieved a Cumulative Grade Point Average (CGPA) of less than 2.5 in 2018 Test 1 (Unit Peperiksaan SBP Johor, 2018). In SBP, students who earn a CGPA of less than 2.5 are categorized as low achievers. The sample of the study involves 200 students from four SBPs in Johor who were chosen through purposeful random sampling aimed at choosing only low achievers (Mohd, 2003). The size of this sample was determined according to the (Krejcie \& Morgan, 1970) Table. As the population size is 350 students, the researcher chose 200 students as a sample for the study.

The data collection was done by distributing questionnaires to identify the relationship between attitude, subjective norm and perceived control to apply the learning practices. Therefore, the researcher used the Learning Practice Questionnaire by Norlia \& Faizah (2016). This questionnaire has item (0.98) and individual (0.88) reliability based on RASCH analysis. Then, the findings were analysed using Pearson correlation in SPSS 25 software to identify the relationship between attitude, subjective norm and perceived behavioural control in learning practices whether positive or negative, strong, moderate or weak or unrelated. Whereas, the value of the degree of strength of the correlation is shown in Table 1.

Table 1: Correlation Relationship

\begin{tabular}{cc}
\hline Correlation between & Interpretation \\
$0.80-1.00$ & Very strong \\
$0.60-0.80$ & Strong \\
$\mathbf{0 . 4 0 - 0 . 6 0}$ & Moderate \\
$\mathbf{0 . 2 0 - 0 . 4 0}$ & Weak \\
$\mathbf{0 . 0 0 - 0 . 2 0}$ & Very weak \\
\hline
\end{tabular}

Source: Sekaran, U. (2006). Research Method for Business: A Skill Building Approach. New Delhi: John Wiley \& Sons. Inc. 


\section{Results and Discussions}

Pearson correlation analysis: To identify the relationship between attitude, subjective norm and perceived behavioural control of learning practices.

Table 2: Correlation relationship between attitude and subjective norm of learning practices

\begin{tabular}{ccc}
\hline $\begin{array}{c}\text { Variables } \\
\text { practices } \\
\text { and }\end{array}$ & Correlationvalue $(\mathrm{r})$ & Significantvalue $(\mathrm{p})$ \\
Subjective norm of learning practices & 0.44 & $0.00^{*}$ \\
\hline significant, $p<0.05$ & &
\end{tabular}

The Pearson correlation analysis shows that there is a significant positive correlation, at a significant level of 0.05 with the coefficient value of $r=0.41$, which is moderately strong between the attitudes towards learning practice behaviour and the perceived behavioural control of learning practices. This means that the higher the attitude towards learning practices, the higher the subjective norm of learning practices and vice versa.

Table 3: Correlation relationship between attitude and perceived behavioural control of learning practices

\begin{tabular}{|c|c|c|}
\hline $\begin{array}{c}\text { Variables } \\
\text { Attitude towards hehaviourof learning }\end{array}$ & Correlationvalue (r) & Significantvalue (p) \\
\hline $\begin{array}{l}\text { practices } \\
\text { and }\end{array}$ & 0.41 & $0.00 *$ \\
\hline $\begin{array}{l}\text { Perceived behavioural control of learning } \\
\text { practices }\end{array}$ & & \\
\hline
\end{tabular}

The Pearson correlation analysis shows that there is a significant positive correlation, at a significant level of 0.05 with the coefficient value of $r=0.44$, which is moderately strong between the attitudes towards learning practice behaviour and the perceived behavioural control of learning practices. This means that the higher the attitude towards learning practices, the higher the perceived behavioural control of learning practices and vice versa.

Table 4: Correlation relationship between subjective norm and perceived behavioural control of learning practices

\begin{tabular}{ccc}
\hline Variables & learning practices & Significantvalue $(\mathrm{p})$ \\
$\begin{array}{c}\text { Subjective norm of learning practices } \\
\text { and }\end{array}$ & Correlationvalue $(\mathrm{r})$ & $0.00^{*}$ \\
$\begin{array}{c}\text { Perceived behavioural control of learning } \\
\text { practices }\end{array}$ & 0.31 & \\
\hline significant, $p<0.05$ & &
\end{tabular}

The Pearson correlation analysis shows that there is a significant positive correlation, at a significant level of 0.05 with the coefficient value of $r=0.31$, which is weak between subjective norm of learning practices and the perceived behavioural control of learning practices. This means that the higher the subjective norm of learning practices, the higher the perceived behavioural control of learning practices and vice versa.

The findings show that there is a significant moderate positive relationship between the attitude and the subjective norm of learning practices as well as between attitudes and perceived behavioural control of learning practices. On the other hand, there is a significant weak positive relationship between subjective norm and the perceived behavioural control of learning practices among SBP low achievers in Johor. The findings show that these three variables are related to each other but the strength of the relationship is not high. The high intention of behaviour can be formed with the result of the response between attitude, subjective norms and perceived behavioural control in which these three elements need to be at a high level so that the resulting intention of the behaviour is high (Ajzen, 2011). 
Hence, these results show that low achievement SBP students in Johor need to be guided in order for them to have high and positive attitude, subjective norm and perceived behavioural control to form the high intentions of learning practices, thus able to apply the learning practices to attain outstanding achievement.However, there is a limitation to the study. This study focuses only on low achievement category of SBP students. Hence, the findings of this study cannot be generalised to other SBP students with high or moderate academic achievement (Fan, 2001; Tee, Leong, \& Abdul Rahim, 2020).

Therefore, future researchers are advised to extend the study using the three variables of this study to diverse samples. Comparison of the subjective norm of learning practices, attitude towards learning practice behaviour and the perceived behavioural control of learning practices involving SBP students with low, medium and high academic achievements can be done for future research. In fact, research samples can also be extended to ordinary daily secondary school students to obtain more comprehensive study findings.

In view of the relationship between the three studied variables, it is suggested that the next study examines the extent of the influence of these three variables on the intention of the learning practices behaviour by using regression analysis. Through the analysis, the researcher can conclude which variables influence the intention of learning practices behaviour among students. In addition, further studies can also focus on the role of behavioural intent as a mediating variable in the relationship between subjective norm, attitude towards behaviour and perceived behaviour control with the practices of learning among students based on the Theory of planned Behaviour (Ajzen, 1991, 2011)

\section{Conclusions}

The results of the study found that the three variables studied; attitudes, subjective norm and perceived behavioural control are interconnected with each other. However, the existing relationship still has not reached a strong relationship where according to the Theory of Planned Behaviour (Ajzen, 1991), these three variables play an important role in helping to increase the potential of high-performing behavioural intentions to apply learning practices among students. Therefore, it is recommended that those involved with SBP, be it at the school level, or the Ministry of Education, to take the initiative of organising more the programs that can enhance the attitude, subjective norm and perceived behavioural control of SBP low achievers to a higher level of practice.This step is expected to be able to produce high-quality behavioural intentions and further enhance the potential of students to apply good learning practices towards outstanding achievements. Therefore, SBP's aspiration to produce a 100 percent target of outstanding students, especially in the Sijil Pelajaran Malaysia (SPM) examinations will be more easily achieved and will then be able to realise the goal of the SBP establishment which aims to produce future scientists, technocrats and professionals (Ministry of Education Malaysia, 2012).

\section{References}

Acevedo, E. O. (2012). The Oxford handbook of exercise psychology: Oxford university press.

Ajzen, I. (1991). The theory of planned behavior. Organizational behavior and human decision processes, 50(2), 179211.

Ajzen, I. (2005). Attitudes, personality, and behavior: McGraw-Hill Education (UK).

Ajzen, I. (2011). Design and evaluation guided by the theory of planned behavior. Soc psychol Eval, Guilford Publications, 74-100.

Ajzen, I., \& Fishbein, M. (2000). Attitudes and the attitude-behavior relation: Reasoned and automatic processes. European review of social psychology, 11(1), 1-33.

Al-Ghazali, I. (2012). Mukhtasar Ihya'Ulumiddin: Perniagaan Jahabersa.

Al-Khaleel, N. A. (2011). Translating Emirati Theater: A Study of Two Plays of HH Sheikh Dr. Sultan Bin Mohammad Al Qasimi.

Al-Qasimi, N. (2010). Immodest modesty: accommodating dissent and the 'abaya-as-fashion in the Arab Gulf States. Journal of Middle East Women's Studies, 6(1), 46-74.

Asy'ari, M. H. (2011). Faktor Adab Dalam Meraih Berkat Ilmu. Terjemahan Kitab Adabul 'Alim Wa Al-Muta'alim. Kuala Lumpur: Pelima Media Sdn. Bhd.

Aziz, A. (2007). Ensiklopedi Adab Islam. Jakarta: Pustaka Imam Asy-Syafi'i.

Beninghof, A. M. (2020). Co-teaching that works: Structures and strategies for maximizing student learning: John Wiley \& Sons.

Costa, K. (2020). 99 Tips for Creating Simple and Sustainable Educational Videos: A Guide for Online Teachers and Flipped Classes: Stylus Publishing, LLC. 
Embong, W. H. W., Safar, A. J., \& Basiron, B. (2020). Teaching Aqidah: Islamic Studies in Malaysia. UMRAN-International Journal of Islamic and Civilizational Studies, 7(1), 25-32.

Fan, X. (2001). Parental involvement and students' academic achievement: A growth modeling analysis. The Journal of Experimental Education, 70(1), 27-61.

Francis, J., Eccles, M. P., Johnston, M., Walker, A., Grimshaw, J. M., Foy, R., et al. (2004). Constructing questionnaires based on the theory of planned behaviour: A manual for health services researchers: Centre for Health Services Research, University of Newcastle upon Tyne.

Gay, L. R., Mills, G.E dan Airasian, Peter. . (2009). ducational Research: Competencies For Analysis And Applications. New Jersey: Pearson Education International.

Ghazali, K. (2015). Aksi teror bukan jihad: Daulat Press.

Heritage, M. (2020). Getting the Emphasis Right: Formative Assessment through Professional Learning. Educational Assessment, 1-4.

Ismail, M. (2014). Konsep Berpikir dalam al-Qur'an dan Implikasinya terhadap Pendidikan Akhlak. Ta'dib: Journal of Islamic Education (Jurnal Pendidikan Islam), 19(02), 291-312.

Kadir, M. N. A. (2014). Memburu Keberkatan Ilmu. Kuala Lumpur: Telaga Biru Sdn Bhd.

Kitchen, J. (2020). Attending to the concerns of teacher candidates in a social justice course: A self-study of a teacher educator. Studying Teacher Education, 16(1), 6-25.

Kraft, P., Rise, J., Sutton, S., \& Røysamb, E. (2005). Perceived difficulty in the theory of planned behaviour: Perceived behavioural control or affective attitude? British journal of social psychology, 44(3), 479-496.

Krejcie, R. V., \& Morgan, D. W. (1970). Determining sample size for research activities. Educational and psychological measurement, 30(3), 607-610.

Lawrence, B. (2020). Research Design The County Diagnostic (pp. 43-94): Springer.

Mohd, N. (2003). Reka bentuk tinjauan soal selidik pendidikan. Skudai: Penerbit UTM.

Noordin, T. A. (2007). Membina pelajar cemerlang: evolusi pembelajaran sepanjang hayat: Penerbit UTM.

Norlia, H. (2017). Sikap, Norma Subjektif Dan Persepsi Mengamalkan Adab Belajar Dalam Pelaksanaan Latihan Hijrah Pelajar Sekolah Berasrama Penuh. Tesis PhD Universiti Teknologi Malaysia, Skudai. .

Oates, R. (2020). The student practitioner in early childhood studies: an essential guide to working with children: Routledge.

Roni, S. M., Merga, M. K., \& Morris, J. E. (2020). Conducting quantitative research in education: Springer.

Sadaf, A., \& Gezer, T. (2020). Exploring factors that influence teachers' intentions to integrate digital literacy using the decomposed theory of planned behavior. Journal of Digital Learning in Teacher Education, 36(2), 124-145.

Salim, N. (2014). An Analysis of Foods and Drinks Based on Qur'an and Sunnah. Universiti Teknologi Malaysia.

Samad, E. A. (2007). Menuju Puncak Kecemerlangan: Tip-Tip Sukses Dari A-Z. : Kuala Lumpur: PTS Millenia Sdn Bhd. .

Steege, M. W., Pratt, J. L., Wickerd, G., Guare, R., \& Watson, T. S. (2019). Conducting school-based functional behavioral assessments: A practitioner's guide: Guilford Publications.

Sun, S., Law, R., \& Schuckert, M. (2020). Mediating effects of attitude, subjective norms and perceived behavioural control for mobile payment-based hotel reservations. International Journal of Hospitality Management, 84, 102331.

Tee, K. N., Leong, K. E., \& Abdul Rahim, S. S. (2020). A Self-Regulation Model of Mathematics Achievement for Eleventh-Grade Students. International Journal of Science and Mathematics Education, 119.

Thohir, M. A., Alfina, C., \& Dardiri, A. (2017). A Comparative Study On Sheikh Az-Zarnuji Thought and Idealism In The Philosophy Of Education. Epistemé: Jurnal Pengembangan Ilmu Keislaman, 12(2), 411433.

Uning, G. S., \& Mohamed, M. (2006). Kajian Ke Atas Faktor-Faktor Yang Mempengaruhi Kelemahan PelajarPelajar Sekolah Berasrama Penuh Dalam Matematik Tingkatan Satu. Universiti Teknologi Malaysia.

Yasin, M. N. (2012). Ibnu Hazm dan ushul fiqh: Refitalisasi ushul fiqh berparadigma burhani: UIN-Maliki Press.

Zadzora, K. M. (2019). Teacher-student Relationship Quality and Student Relatedness and Engagement in Elementary School. 